\title{
OWNERSHIP STRUCTURES, INVESTORS CONFIDENCE AND FINANCIAL DECISIONS IN FAMILY FIRMS: EVIDENCE FROM GCC MARKETS
}

\author{
Muhammad Sadiq Shahid \\ Assistant Professor, Institute of Management Sciences, BZU Multan \\ Razaz Houssien Felimban \\ PhD Scholar at Middlesex University, UK \\ Khawar Naheed \\ Assistant Professor; Bahauddin Zakariya University, Multan, Pakistan \\ Usman Aleem \\ PAK-KITE, Karachi, Pakistan \\ Shaiza Nawaz \\ MPhil Scholar at School of Economics, Bahauddin Zakariya University Multan
}

\begin{abstract}
The objective of this study is to examine the impact of financial decisions on the ownershipstructure. This study adopted two themes of ownership structure (e.g., $25 \%$ \& $50 \%$ ) thatcategorized the family-owned firms (FOF) and non-family firms (NFOF). The data wascollected from 286 firms listed at GCC stock exchanges annual reports, stock exchangedatabase, and DataStream that range from 2010-2016 periods. The findings of this study showed that the FOFs have lesser investment-internal fund sensitivity than NFOFs. Though, there is an insignificant effect of the block holder on investment funds sensitivity. However, the little implication of dividend payout in FOFs as compare to NFOFs was disclosed in the results. Moreover, it wrapped up that there are less agency problems and informationasymmetry in FOFs comparatively.

Keywords: Ownership structure, Investment sensitivity, Family-firms, financial decision, Gulf Cooperation Council (GCC)
\end{abstract}

Jel Classification: G30: G31,G32

*The material presented by the author does not necessarily portray the view point of the editors and the management of the Ilma University - Formerly IBT

1. Muhammad Sadiq Shahid

:sshahidmalik@bzu.edu.pk

: razazhoussien@gmail.com

3. Khawar Naheed $\quad$ : khawarnaheed@bzu.edu.pk

4. Usman Aleem : musmanaleem@live.com

5. Shaiza Nawaz : shazianawaz@gmail.com

CILMA-JBS is published by the Ilma University - Formerly IBT

Main Ibrahim Hydri Road, Korangi Creek, Karachi-75190, Pakistan 


\section{INTRODUCTION AND BACKGROUND}

Family businesses have become an important business model in the world, which can play a critical role in the development of developed and emerging markets economies. The study of Chase, (2015) showed that families own a large number of business corporations across the globe; about 80-90\%, firms in the USA are FOFs; in Europe, $80 \%$ firms are operating under family control. The ratios of FOFs to NFOFs are ranging from $70-85 \%$ in the Middle East and 65-75\% for Australia. Most of the Chinese and Japanese firms consist on FOFs. Similarly, 85\% Indian firms are working under the control of families (Sapovadia, 2013). In Pakistan, the family owned firms play is dominant and play an important role in the growth of the country (Tahir, \& Sabir, 2015). Similarly, in Arab countries, the majority of the listed firms are family owns the firm (Al-Ghamdi \& Rhodes, 201). In family owned firms, it is very frequent for a family member to hold a significant power in the top management. This power possibly attained through being a Chief Executive Officer (CEO) or board member, and may through the mechanism of senior management positions (OECD, 2003). This can be is a major reason of agency conflicts between the controlling family and all types of shareholders, such as minority stakeholders and block holders. That is why in the Arab countries, it is essential to apprehend the corporate governance (Al-Ghamdi \& Rhodes, 2015; Najib, 2007; Omet, 2005; Saidi, 2005, 2006).

The ownership structure can be used as an instrument to moderate the conflicts between owners and managers. This ownership has the capability to affect the potential course of business operations that might influence the financial decisions including investment and dividend. Owners can play a significant role in the survival of firms and may have different motivations in the management of firms. Owners invest capital to get a higher return in the form of revenue (dividend payments) and capital gains (increase in share price). Therefore, owners instinctively tend to make any financial decisions for the betterment of business organizations.

The study of Modigliani \& Miller (1958) pointed that financial decisions are entirely autonomous of a capital structure of the firms in the ideal capital market circumstances. However, the existing finance literatures indicated that the efficient capital markets exist globally. In contrast to $M \& M$ (1958) assumptions, the impact of firm ownership on financial decision can be explained generally from knowledge of inefficient capital markets. Such types of the capital markets are not only associated with the financial decisions of firms, although linked with capability of the funds through investment- internal finance. Although in the 1950s, the cash flow association with optimal level of investment has been debated (Meyer \& Kuh, 1957, however, the question regarding internal investment sensitivity stills debatable and unanswered in the literature (Hovakimian, 2009). In this concern, Morgado \& Pindado (2003) argued and evidenced the importance of optimal level of investment in order to maximize the firm value. The study argued that the problem of overinvestment (underinvestment) is consequence of mismanagement of capital structure by managers.

Although, financial decision has become a hot topic in recent literature, however, only a small number of studies have analysed whether family control ownership influenced financial policies of business organization (e.g., Tahir \& Sabir, 2015 and Frank \& Goyal, 2009). Recently, regardless of finance literature that discovered the factors that influence debt and dividend policies (e.g., Tahir \& Sabir, 2015 and Frank \& Goyal, 2009). However, the association between financial policies and ownership structure, particularly in case of FOFs and NFOFs is limited. 
There are several theoretical frameworks and financial models that were established to discover the determinants of corporate value of business organization such as dividend policy in conjunction with debt policy. Among the theories that explain optimal capital structure, trade-off theory (TOT) and pecking order theory (POT) explains the optimal capital structure of the firm (Myers \& Majluf, 1984). These two theories describe the factors that contribute in towards firm's financial decisions making. Hail et al., (2014) pointed that the managers are reluctant to reduce dividend payments; it might adversely influence stock price; subsequently, a dividend payout ratio remains steady over time. Von Eije \& Megginson (2008) explored the company's choice between shares repurchase and dividend payments. They found that dividend payout ratio is an effective mechanism for corporate governance of the companies. DeCesari, \& Ozkan (2015) also confirm the firm's preference of dividend payments over shares repurchase.

In the GCC countries family own firms facade the dual confronts of operating in a difficult international environment. In order to survive, the family member are replaced to the run the operation of firms that have achieved lasting accomplishment internationally, and the firms have to reclaimed the "restless entrepreneur" syndrome, and develop and enact a long-term strategy to manage the family firms operation.

In order to achieve the objectives of research, the main analysis of financial decisions has been divided into two parts. First, the investment decision is examined in terms of family and non-family ownership structure. Second, the attempt is made to analyse the role of ownership structure in dividend policy of firms. Furthermore, in view of the dynamism of financing decisions making, this study investigated those factors that stabilized dividend payout and investment policies.

\subsection{Objectives of study}

According to the above discussion, the following objectives are established;

- To examine the impact of ownership structure on investment policy regarding FOFs and NFOFs.

- To investigate the relationship between corporate governance and investment policy in FOF and NFOFs.

- To examine financial decision can enhance the investor confidence in FOFs and NFOFs.

- To make recommendations and suggestions according to empirical evidence.

The rest of the paper is structured as follows. Section II presents the review of literature and hypothesis's development. Section III presents the research design and data definitions. Section IV presents the empirical results and last section concludes the paper.

\section{REVIEW OF LITERATURE AND HYPOTHESES DEVELOPMENT}

Existing literature related to the family owned firm is comprehensive but it is very hard to find the agreement on the precise definition of a family firm. Though, the distinctive family business has been categorized as an organization that is controlled and managed by several family members (Lansberg, 1999 and Shanker \& Astrachan, 1996), regularly from many generations (Gomez-Mejia et al., 2007; Anderson \& Reeb, 2003).

Family-owned business (FOB) has several potential advantages that it reduce investmentcash flow sensitivity because of the following rationale; Firstly, similar to arguments of diverse researchers like Galeotti et al., (1994) that the advantages that are linked with family ownership facilitate in reducing deficiency of financial markets. Secondly, Schulze et al., 
(2003) pointed that family owned firm appraise good investment projects because of profound knowledge and long- term involvement of family members in the business functions that in turn decrease the deviation from the optimal level of new investment. Thirdly, the family owned firm's helps to reduce the agency cost among stakeholders who directs lower the wedge between cost of an external and internal fund (Jensen \& Meckling, 1976). This little financial constraint make possible to choose optimal investment that at last moderates the investment-cash flow sensitivity. Finally, previous literatures of family firms indicated that the family owner's concern regarding reputation of business increase the earning quality that reduces the agency conflicts. Subordinate agency conflict improves the corporate investment sensitivity in family-owned business organization. Keeping in view the above discussion, therefore, it is concluded that the family owned firms showed lower cash flow sensitivity as compared to non-family owned firms.

The theory of intervention and voice argued that active monitoring of managers by large shareholders having substantial stakes called ownership concentration which enhances firm value. Such kind of actions called shareholder's activism which prevents the managers from doing inefficient activities; as a result of business organization destroy. This type of shareholder activism provides disadvantage to the largest shareholders and helps to moderate the investment of internally generated funds. Porta et al., (1999) found that firms with concentrated ownership provide the potential benefits that overall discipline the corporation. The existence of block holders crafts with good monitoring prevents the managers to attain individual benefits from investment decision. Thus, it can be concluded that FOFs can achieve the best investment level than NFOFs. Hence, FOFs has less cash flow sensitivity in the existence of general block holders.

The literatures related to debt policy of family owned business discovered the impact of family ownership structure on debt policy that is whether family owned business believe in control- mechanisms or not. The control of family reduced the agency conflicts and asymmetric information, which is associated with financing policy and assisting FOFs to external financing. If family control ownership effectively moderates agency conflict among stakeholders, particularly, debt holders and shareholders, they are be less inhibited when obtain external finance. Thus, the negative impact of external and internal financing on capital structure reported in previous study (Almeida \& Campello, 2010). FOBs build a longterm connection with external fund suppliers for better financing terms (De Miguel et al., 2004). Therefore, there are less chances and limitations for having internal financing.

Agency theory explains that the agency conflict arises when the manager provides a service to another employee and then delegate decision-making authority to the agent (Jensen and Meckling, 1976). These associations also exist among all types of shareholders, such as, larger shareholders, bondholders and minor shareholders as a corporate manager, the manager will be more aware of internal information and corporate prospects than the owners (shareholders).

According to Jensen and Meckling (1976), agency conflicts arise due to the separation of ownership and control of the firms, as results it affects the firm value. The separation of ownership and control also described by Fama (1980), a well-organized form of economic organization in the perspective of "a set of contracts." Although recent international evidence advocates that families may be unhelpful to firm performance. Miller et al., (2007) in their study investigated such types of contrasting findings of family owned firms in the USA, but fundamentally neglected distinction between sole founder businesses in which no relatives of 
a founder are involved, and true family businesses that include multiple family members as owners or managers.

Konijn, et al., (2011) documented a negative association between Tobin's Q and blockholders dispersion by using USA firm data. The findings of their study were robust to a wide variety of model specifications, controls and difference found in their results with other geographic regions such as Europe and Asia.

In emerging markets, ownership structure, investment, and financial decisions significantly affect firm value. Tahir and Sabir (2015) also examined the investment and financing policy with regard to ownership structure. They employed two levels of ownership ( $25 \%$ \& 50\%) structure to differentiate between family owned firm (FOF) and non-family owned firms (NFOF). Tahir and Sabir (2015) collected data from 280 firms listed at Karachi Stock Exchange from 2002-2013 and found that the investment-internal fund sensitivity of FOFs is lower as compared to NFOFs. Hence, the blockholders influenced investment-internal fund sensitivity. Additionally, they evidenced higher payout ratio in FOFs as compare to NFOFs. Finally, they concluded that there is a lower agency and information asymmetry issues in FOFs relatively.

Sonfield et al., (2015) compared the US family businesses with Arab family owned businesses (Egypt, Kuwait and Lebanon), with regard to the degree to which top management has formulated specific plans for the future succession of junior family members into top management positions. They evidenced that the top managers of Arab family owned businesses are engaged in the formulation of such succession plans statistically in a greater degree than US managers.

Al-Ghamdi and Rhodes (2015) examine the relationship between family ownership, corporate governance and performance. The study data of 792 firms listed in Saudi Stock Exchange from 2006-2013 and found that ownership concentration has no systematic impact on firm performance (measured by ROA). However, ownership concentration of family owned firms (FOF) have a significant positive relationship with Tobin's Q. There is a strong relationship between performance and managerial ownership (both measured ROA and Tobin's Q) in FOFs, and contrast to NFOFs. Furthermore, the study results indicated that $\mathrm{CEO}$ non duality is very important for performance in family owns firms.

Board of directors of firm plays an important role in the corporate governance of any company. It is the responsibility of the firm to get the approval and oversight of its objectives, risk tolerance and management, internal controls system, corporate governance, and compensation system. The firm is also responsible for overseeing senior management and board should exercise objective judgment independently about senior management, shareholders, and any other interest. A good practice of the firm includes the appointment of number of qualified and independent non-executive board members that include board members representing minority shareholders.

Nasrum (2013) used the data of stock ownership structure, number of audit committee, board size, board independence and price of shares of listed firms at Indonesia Stock Exchanges from 2000-2009. The results indicated that the corporate governance index and ownership structure has a positive impact on investment decisions and the corporate governance was positively associated with dividend policy. Overall results showed that the ownership structure, investment and financing and dividend decision have a positive influence on the firm value. As such, there are many existing theories related to multiple blockholders 
structures are negatively associated. This is well explained by Pecking Order Theory (POT) that firm prefers to debt financing relatively as compare to equity financing when internal fund is inadequate.

\subsection{Theoretical Framework and Null Hypotheses}

This study assumed a higher dividend payout relatively in FOFs as compared to NFOFs because of following motives: Firstly, the dividend policy can be used as control mechanisms to reduce agency cost within family-owned firms. Therefore, FOFs need to distribute high dividends in order to decrease agency clashes that increase control mechanism, which a major key requirement of family owners. Secondly, family-owned firms can be employed dividend policy to moderate the expropriations of large shareholders and for good corporate governance practices. In view of the above point of view, this study anticipates that more dividend in FOFs as compared to NFOFs. Similarly, debt policy of companies' shows difference for FOFs and NFOFs.

To investigate the association between ownership structures, investor confidence and financial decision in FOFs and NFOFs in GCC stock markets. Keeping in view the above discussion, following hypotheses are formulated as:

H1: There is lower investment-internal sensitivity in FOFs than NFOFs.

$\mathrm{H} 2$ : There is lower investment-internal sensitivity in FOFs than NFOFs after controlling the blockholders effect.

H3: The investor confidence is lower in FOFs than NFOFs.

H4: The investor confidence is higher in FOFs than NFOFs after controlling market risk effect.

H5: There is a higher dividend payout ratio in FOFs as compared to NFOFs lead high confidence among investors.

\section{METHODOLOGY}

This study collected data of 286 firms listed at GCC stock exchanges from 2010-2016 period. The main sources of data are annual reports, DataStream, Gulfdatabase and Bloomberg. This study investigated the following constructs: corporate investment(INVit), industry adjusted investment (IAIit), internal fund (IFit), Investor confidence(ISIit), market risk(MRit), Corporate Governance(CG), Tobin Q (Qit), debt ratio (LEVit), dividend payout ratio (DIVit) and net earnings (NEit). Furthermore, family-owned firms (FOF) and blockholders effect $(\mathrm{BH})$ were used as dummy variables, while firm size (FSIZEit), Sales of firm (Saleit), average account receivables (ARit) and firm's age (AGEit) were consider as control variables. The time series cross-sectional data may contain heterogeneity and endogeneity problems (McVey \& Draho, 2005 and Demsetz \& Villalonga, 2001). To resolve these problems, this study employed panel data and generalized method of moments for analysis. Panel data solve the problem of heterogeneity (Allegretto et al., 2011) and Generalized Method of Moments (GMM) controls the problem of endogeneity (Chausse, 2010). Moreover, the misspecification of the model was tested by Hansen J-statistic and validity of GMM -IV variable by Sargan test.

The definition and the measurement of all variables are explained in table 1. The main variable of this study, investor confidence, has been constructed by following studies (Bandopadhyaya \& Jones, 2006; Baker \& Wurgler, 2006). The ISI works out as follows: 


$$
I S I=\frac{\sum\left(R_{i}-R_{i}^{\wedge}\right)\left(S_{i}-S_{i}^{\wedge}\right)}{\left[\sum\left(R_{i}-R_{i}^{\wedge}\right)^{2} \sum\left(S_{i}-S_{i}^{\wedge}\right)^{2}\right]^{1 / 2}}
$$

Where; Ri monthly return for security $\mathrm{i}$, and $\mathrm{Si}$ are the rank of historical volatility for security $\mathrm{i}$, as well as $\mathrm{Ri}^{\wedge}$ and $\mathrm{Si}^{\wedge}$ are the population means return and historical volatility rankings.

Following Richardson (2006), we use the new investment to proxy the corporate investment decision. New investment (INVEST) is calculated as total investment expenditure minus amortization and depreciation expense. The total investment expenditure includes required investment expenditure to maintain the existing assets and investment expenditure on new projects. As for corporate governance variables, we used the board size (BODSIZE) and Board independence to measure the monitoring effects (efficiency and independency) of corporate governance. We use the dummy indicator for the existence of audit and remuneration committee.

The industry adjusted investment (IAIit) has been calculated by adding depreciation expenses of preceding year to increase in net fixed assets and deducted by industry median. The median was preferred to calculate the central tendency than mean and mode due to its effectiveness against such kind of skewed data contemplated with outliers (Morgado \& Pindado, 2003). Internal fund (IFit) and net earnings (NEit) were computed as; the depreciation expense of corresponding year was added back to net earnings for the calculation of the internal fund (IFit). Third, Tobin q (Qit) was taken as a proxy of investment opportunities. Other control variables comprise free cash flow (CFit), dividend payout/total asset (DIVit) variables because the reinvestment rate depends on how much earnings left after payout to the shareholder, firm size (FSIZEit) and ROAit. As Grundy and Li (2010) and Richardson (2006) find that cash flow has a positive impact on investment. Moreover, firms tend to invest more when they have more investment opportunities. In existing researches, Tobin's Q use as a proxy for investment opportunities (Grundy and Li, 2010, Richardson, 2006, among others). Tobin's Q is measure as a ratio of market value and book value of the total assets (Chung \& Pruitt, 1994). Furthermore, a set of control variables Sales of firm (Salesit), market risk (MRit) and firm's age (AGEit) were used.

Two dummy variables (FOB \& $\mathrm{BH}$ ) were also used in the estimation procedure. FOB was used as a family business dummy took value 1 for family business, 0 otherwise. Family own firm (FOFs), where directors belong to family have managerial ownership (voting rights) between $25 \%$ and $50 \%$ in the firm (which are recommended by GEEF (GEEF, 2008). This was in agreement with the classification used by Board of Family Business Network (BFBN, 2008). We adopt the 50\% cut-off point for the reason that ownership at this level converses explicit control rights (Doidge et al., 2009). In GCC, family owners hold more than 50\% shareholding (Santos, 2015). The dummy variable for blockholders effect (BH) equal to 1 for the FOFs having $10 \%$ ownership other than family owners \& 0 for otherwise. 


\section{Table 1: The Variable Description}

\begin{tabular}{|c|c|c|}
\hline Variable & Symbol & Variable Meaning and Narrative and \\
\hline Investment & $\mathrm{INV}_{\text {it }}$ & $\begin{array}{l}\text { The summation of all outlays on capital expenditure, acquisitions, R\&D and } \\
\text { receipts from the sale of property, plant and equipment minus amortization and } \\
\text { depreciation expense. }\end{array}$ \\
\hline $\begin{array}{l}\text { Industry } \\
\text { adjusted } \\
\text { investment }\end{array}$ & IAIit & $\begin{array}{l}\text { The sum of all outlays on capital expenditure, acquisitions, } \mathrm{R} \& \mathrm{D} \text { and receipts } \\
\text { from the sale of property, plant and equipment minus amortization and } \\
\text { depreciation expense subtracted by industry median investment. }\end{array}$ \\
\hline Blockholders & BHit & $\begin{array}{l}\text { This dummy variable value } 1 \text { for presence of block holder's effect and zero } \\
\text { otherwise (ownership } \% \text { of all major }(>5 \%) \text { non-family founder owners). }\end{array}$ \\
\hline $\begin{array}{l}\text { Dividend pay- } \\
\text { out ratio }\end{array}$ & DIVit & This variable measured as Dividends/net income \\
\hline Internal fund & IFit & This variable measured as debt and internal fund ratios \\
\hline $\begin{array}{l}\text { Investor } \\
\text { Confidence }\end{array}$ & SENTI $_{\text {it }}$ & $\begin{array}{l}\text { Investor confidence indexes are constructed by using turnover growth rate of } \\
\text { individual stock }\end{array}$ \\
\hline net earnings & NEit & $\begin{array}{l}\text { This is measure as earnings per share (excluding extraordinary items and } \\
\text { discontinued operations), scaled by beginning-of-period Price. }\end{array}$ \\
\hline $\begin{array}{l}\text { Board } \\
\text { independent }\end{array}$ & BINDit & Unbound members to all members of board of company \\
\hline Board Size & BSIZEit & Total members existed in the board of company \\
\hline Family firms & FOF & The dummy variable FOF equal 1 for family ownership, otherwise zero \\
\hline Market risk & MRit & Market risk is measure as debt/market value of equity \\
\hline Debt ratio & LEVit & Debt ratio calculated as total debt divided by total assets \\
\hline Cash flow & $\mathrm{CF}_{\mathrm{it}}$ & $\begin{array}{l}\text { The cash flow as the sum of earnings before extraordinary items and depreciation } \\
\text { deflated by total assets. }\end{array}$ \\
\hline Tobin's Q & $\mathrm{Q}_{\mathrm{it}}$ & Total assets market value deflated by the book value of total assets \\
\hline Firm size & FSIZE $_{\text {it }}$ & Size measured as the logarithm of total assets at the start of year. \\
\hline Sales of firm & SALEit & This variable measured as firms annual net sales \\
\hline Firm age & $\mathrm{AGE}_{\mathrm{it}}$ & This variable measured as the logarithm of number of years since firm operating. \\
\hline
\end{tabular}

Table.2: Descriptive Statistics-whole Sample

\begin{tabular}{|l|l|l|l|}
\hline Variables & Mean & Median & St. Dev. \\
\hline INVit & 0.109 & 0.096 & 0.837 \\
\hline IAIit & 0.064 & 0.034 & 0.963 \\
\hline LEV it & 0.708 & 0.743 & 0.361 \\
\hline BSIZEit & 5.149 & 4.00 & 0.960 \\
\hline BINDit & 3.298 & 4.607 & 0.495 \\
\hline SENTIit & 0.836 & -0.091 & 0.629 \\
\hline CFit & 1.291 & 1.186 & 0.763 \\
\hline DIVit & 0.002 & 0.001 & 0.003 \\
\hline IFit & 0.060 & 0.053 & 0.191 \\
\hline NEit & 5.672 & 4.891 & 1.291 \\
\hline MR it & 0.148 & 0.096 & -0.960 \\
\hline Qit-1 & 1.682 & 1.679 & 0.086 \\
\hline FSIZE it & 9.159 & 7.927 & 1.325 \\
\hline SALEit & 3.481 & 2.390 & -1.630 \\
\hline ROAit & 0.0799 & 0.029 & 1.086 \\
\hline
\end{tabular}

Note: This table presents the means, medians and standard deviations of all variables in the system. The INVit and IAIit are the corporate investment and industry adjusted investment. LEVit is debt ratio and DIVit is dividend payout ratio; BSIZEit and BINDit are proxy for corporate governance. IFit stands for internal fund; ISENTI ${ }_{i t}$; investor confidence; Qit 
denotes Tobin q; and NEit is the net earnings of firms. CFit is cash flow and MRit, market risk, ROAit is return on assets, ARit is account receivable, FSIZEit is firm size, SALEit is firm sales and AGEit is age of firms.

Table-2 provides the descriptive statistics of the variables of interest in this study. The average value of corporate investment is 0.064 and $\mathrm{Tobin} Q=1.682$ shows a remarkable gap between book values and market value of firms. The average value of Sales and ROA are 7.99\% and 3.481 respectively, which indicated good sign regarding family own business operations. The investor's confidence proxy's mean value is approximate 0.836 , the medium is a negative and the standard deviation is 0.629 .

Table 3 reports the correlation results of the variables of interest of the sample used in this study. The correlation between the investor confidence and corporate governance is positive and significant at $1 \%$ and $5 \%$ level of significance.

Table .3: Pearson correlations Matrix Analysis

\begin{tabular}{|c|c|c|c|c|c|c|c|c|c|c|c|c|c|c|}
\hline Variables & 1 & 2 & 3 & 4 & 5 & 6 & 7 & 8 & 9 & 10 & 11 & 12 & 13 & 14 \\
\hline $\begin{array}{l}\text { 1. INVit } \\
\text { 2.IAIit }\end{array}$ & $0.038 * *$ & & & & & & & & & & & & & \\
\hline 3.LEV it & $0.049 *$ & $0.046^{* * *}$ & & & & & & & & & & & & \\
\hline $\begin{array}{l}\text { 4.DIVit } \\
\text { 5.SENTIit }\end{array}$ & $\begin{array}{l}0.071^{*} \\
0.250^{*}\end{array}$ & $\begin{array}{l}0.086 \\
0.051^{*}\end{array}$ & $\begin{array}{l}0.075 \\
0.268^{*}\end{array}$ & $0.383 *$ & & & & & & & & & & \\
\hline 6.CFit & 0.043 & $0.024 *$ & $0.034 *$ & 0.345 & 0.126 & & & & & & & & & \\
\hline 7.BINDit & $0.017 * *$ & 0.131 & $0.143^{* *}$ & $0.019 *$ & 0.170 & 0.214 & & & & & & & & \\
\hline 8.BSIZEit & $0.062 *$ & 0.051 & $0.039^{*}$ & 0.040 & $0.031^{* *}$ & 0.026 & 0.033 & & & & & & & \\
\hline 11.MR it & $0.032 *$ & 0.048 & $0.064 *$ & $0.092 *$ & $-0.169^{*}$ & -0.068 & 0.056 & $0.064^{*}$ & $0.084 *$ & $-\overline{0.054 *}$ & & & & \\
\hline 12.Qit & $0.168 *$ & $0.071^{*}$ & $0.021^{*}$ & $0.157 * *$ & 0.158 & $0.134 * *$ & 0.187 & 0.056 & $0.062 * *$ & 0.027 & $0.070^{*}$ & & & \\
\hline 13. ROAit & $0.082 *$ & $0.028 * * *$ & $0.077 *$ & $0.299 *$ & $0.479^{*}$ & 0.541 & 0.036 & 0.050 & $0.047 *$ & 0.035 & 0.014 & $0.067 *$ & & \\
\hline 14.SALEit & 0.048 & $0.036^{*}$ & $0.043^{*}$ & 0.059 & $0.098^{* *}$ & 0.036 & 0.046 & 0.047 & 0.392 & 0.042 & $0.064^{* *}$ & 0.051 & $0.341^{*}$ & \\
\hline 15.FSIZEit & $0.092 *$ & $0.084 *$ & $0.082 *$ & $0.016^{*}$ & 0.048 & $0.013^{*}$ & $0.023^{*}$ & $0.060^{*}$ & 0.313 & $0.050^{*}$ & $0.013^{*}$ & $0.030^{*}$ & $0.362 *$ & $0.029 *$ \\
\hline
\end{tabular}

Note: This table presents the details of Pearson correlation between variables. The INVit and IAIit are the corporate investment and industry adjusted investment. LEVit and DIVit are the debt ratio and dividend payout ratio respectively BSIZEit and BINDit are board independent and board size use as proxy for corporate governance. IFit stands for internal fund; ISENTIit; investor confidence; Qit denotes Tobin q; NEit is the net earnings of firms, CFit is cash flow and MRit, market risk, ROAit is return on assets, FSIZEit is firm size, SALEit is firm sales and AGEit is age of firms. ***Significant at 1\% level, **significant at 5\%level \&* significant at $10 \%$ level respectively.

In panels, the correlation coefficients between corporate investment and the measures of corporate governance are positive and significant except board size because investors have a perception that larger board size reduces the profitability of the firm. This study finds a positive association between corporate investment and investor confidence. The board independence is found to be positively associated with the confidence of investors, while firm size is also positively associated with both measures of corporate governance. The dividend payout is positively association with investment, investor confidence and other variables. Moreover, the maximum correlation coefficient value is about 0.541 , so multicollinearity is unlikely to be a serious concern. Furthermore, the VIF test was employed to observe the collinearity problem in because due to this the variance of the regression coefficients may 
unstable. The results of VIF test for individual independent variable is less than 2.5 and differs from 2.462 to 1.284 that indicated that there is no multocillinearity issue.

The results resorted in table 4 indicate that FOFs have significantly different behaviour in terms of corporate investment (INVit), debt ratio (LEVit) and dividend payout ratio (DIVit). Though, this variation is further prominent when investment and debt ratio are used to capture the financial behaviour of firms. The results also indicate the significant difference between dependent variables, thus comparison seems to be valid.

Table-4 Univariate tests of dependent variables

\begin{tabular}{|l|l|l|l|l|l|}
\hline & & All Firms & FOF & NFOF & P-value \\
\hline \multirow{4}{*}{$\begin{array}{l}\text { Means Difference tests using } \\
\text { 25\% cut-off points }\end{array}$} & INVit & 0.2648 & 0.1468 & 0.2386 & $0.040^{* *}$ \\
\cline { 2 - 6 } & LEVit & 0.7436 & 0.6870 & 0.9443 & $0.064^{*}$ \\
\cline { 2 - 6 } & DIVit & 0.0247 & 0.0169 & 0.0128 & $0.001^{* * *}$ \\
\hline \multirow{3}{*}{$\begin{array}{l}\text { Means Difference tests using } \text { cut-off points } \\
\text { INVit }\end{array}$} & 0.1849 & 0.1628 & 0.2394 & $0.074^{*}$ \\
\cline { 2 - 6 } & LEVit & 0.7432 & 0.6776 & 0.8419 & $0.084^{*}$ \\
\cline { 2 - 6 } & DIVit & 0.0196 & 0.0147 & 0.0186 & $0.042^{* *}$ \\
\hline
\end{tabular}

Note: This table presents means difference tests between FOFs and NFOF investment behaviours. The variable IAIit is corporate investment measure; LEVit and DIVit are the debt ratio and dividend ratio. The FOFs and NFOFs are classified according the definition of family firms (. reference). HO: Mean of variables FOFs -Mean of variables of $\mathrm{NFOF}=0$. ** *Significant at $1 \%$ level, **significant at 5\%level \&* significant at $10 \%$ level respectively.

\section{EMPIRICAL RESULTS}

This study conducts time series cross-sectional and panel analysis to examine the relationship between ownership structure, investor confidence, and corporate investment decision in FOFs. In model (1), the dependent variable is a corporate investment (INVit) and independent variables include investor confidence (ISIit), industry adjusted investment (IAIit), corporate governance (GCit), firm size (size), cash flow (CFit), Tobin Q (Qit)and ROA as measures of firm performance, internal fund (IFit), market risk(MRit), debt ratio (LEVit), dividend payout ratio (DIVit) and net earnings (NEit). The family-owned firms (FOFi) and blockholders effect (BH) are used as dummy variables, while firm size (FSIZEit), Sales (SALEit) and age (AGEit) are considerd as control variables.

In model 2, the interaction term between investor confidence and corporate investment (SENTIit*CGit) is added to examine the relationship between confidence of investors in the level of investment at different level of corporate governance. Our models written as:

$$
\begin{aligned}
& I^{I N E S T} T_{i t}=\alpha+\beta 1 I F_{i t}+\beta 2 D I V_{i t}++\beta 3 \mathrm{BODIND}_{i t}+\beta 4 \mathrm{BSIZE}_{i t}+\beta 5 \mathrm{AUDTC}_{i t}+\beta 6 C F_{i t} \\
& { }_{+} \beta 7 \mathrm{SENTI}_{i t}+\beta 8 Q_{i t}+\beta 9 N E_{i t}+\beta 10 M R_{i t+} \varepsilon_{i t} \\
& I_{i t}=\alpha+\beta 1 I F_{i t}+\beta 2 D I V_{i t}++\beta 3 \mathrm{BODIND}_{i t}+\beta 4 \mathrm{BSIZE}_{i t}+\beta 5 \mathrm{AUDTC}_{i t}+\beta 6 C F_{i t}+\beta 7 S E N T I_{i t+} \\
& \beta 8 Q_{i t}+\beta 9 N E_{i t}+\beta 10 M R_{i t+} \varepsilon_{i t}
\end{aligned}
$$

Where: $\beta$ is coefficient of variables; INVESTMENT $=$ dependent variable, proxies corporate new level of investment. SENTI is proxy of Investor confidence; BODSIZE is Size of Board 
is the number of directors in the board. BODIND is Board independence, measured as the ratio of the number of independent directors over the number of non-independent directors. AUDTC is the existence of an internal audit committee in the Board structure. $\mathrm{CF}$ is free cash flows to the firms; SIZE = size of firm, $Q=$ Tobin $Q$ as measure of performance are independent variables in this model. $\varepsilon_{i t}$ : error terms clustered by industry. Moreover, an interaction term (FOFit*IFit, FOFit*NEit, BHit*IFi) is added to examine the relationship between variables. Further, we employed model 3 and 4 to examine "the best corporate governance practices reduce information asymmetry, hence affect the investor confidence.

$$
\begin{aligned}
& \text { IAIit }=\alpha 0+\phi \text { IAIit- }+(\beta+\gamma \text { FOF }) \text { IFit }+\delta 1 \text { Qit- } 1+\text { Xit- } 1+€ \text { it } \\
& \text { IAIit }=\alpha 0+\phi \text { IAIit- } 1+(\beta+\gamma \text { FOF }+\delta \text { BH }) \text { IFit }+\delta 1 Q \text { it- } 1+\text { X it- } 1+€ \text { it } \\
& \text { LEVit }=\alpha 0+\phi 1 \text { LEVit- } 1+(\beta+\gamma \text { FOF }) \text { IFit }+ \text { Xit- } 1+€ i t \\
& \text { DIVit }=\alpha 0+\phi 2 \text { DIVit- } 1+(\beta 1+\gamma 1 \text { FOF }) \text { NEit }+ \text { Xit- } 1+€ \text { it }
\end{aligned}
$$

Where: IAIit= Industry adjusted investment; IFit= Internal fund; Qit $=$ Tobin Q used as a proxy of investment opportunity; FOFs = Dummy variable for family firms; LEVit $=$ Debt

\begin{tabular}{|c|c|c|c|c|c|}
\hline Variables & OLS & RE & 2SL & 2SL & 2SL \\
\hline constant & $\begin{array}{c}0-0.0460^{*} \\
(1.827)\end{array}$ & $\begin{array}{c}-0.0552^{*} \\
(0.046)\end{array}$ & $\begin{array}{c}0.0426^{*} \\
(0.029)\end{array}$ & $\begin{array}{c}0.0543^{*} \\
(0.026)\end{array}$ & $\begin{array}{c}0.0627^{*} \\
(0.039)\end{array}$ \\
\hline $\mathbf{I F}_{\text {it }}$ & $\begin{array}{c}-0.0802^{*} \\
(0.040)\end{array}$ & $\begin{array}{l}-0.0691 \\
(0.905)\end{array}$ & $\begin{array}{c}-0.0783 \\
(0.256)\end{array}$ & $\begin{array}{c}-0.0740 \\
(1.062)\end{array}$ & $\begin{array}{l}-0.0685 \\
(0.097)\end{array}$ \\
\hline FOF*IF ${ }^{i t}$ & $\begin{array}{c}0.1404 * \\
(0.089)\end{array}$ & & $\begin{array}{c}-0.1406 * * * \\
(0.008)\end{array}$ & $\begin{array}{c}-0.1127 * * * \\
(0.005)\end{array}$ & \\
\hline BH*IFit & $\begin{array}{l}0.0028 \\
(0.749)\end{array}$ & & & & \\
\hline $\mathrm{NE}_{\text {it }}$ & $\begin{array}{l}0.0045 \\
(0.603)\end{array}$ & & & & \\
\hline$F O F * N E_{i t}$ & $\begin{array}{c}0.0156^{* * * *} \\
(0.002)\end{array}$ & & & & \\
\hline $\mathbf{Q}_{\text {it }}$ & $\begin{array}{c}-0.0143 * * * \\
(0.001)\end{array}$ & & & & \\
\hline $\mathbf{Q}_{\mathrm{it}-1}$ & & & $\begin{array}{c}0.0162 * * \\
(0.009)\end{array}$ & & \\
\hline $\mathbf{I A I}_{\mathrm{it}-\mathbf{1}}$ & & & & $\begin{array}{c}0.0192 * \\
(0.010)\end{array}$ & \\
\hline $\mathbf{C F}_{\text {it }}$ & $\begin{array}{l}0.0190 \\
(0.062)\end{array}$ & $\begin{array}{l}0.0225 \\
(0.097)\end{array}$ & $\begin{array}{l}0.0316 \\
(0.325)\end{array}$ & $\begin{array}{c}0.0394 * * * \\
(0.001)\end{array}$ & $\begin{array}{c}0.0417^{*} \\
(0.017)\end{array}$ \\
\hline $\mathbf{C F}_{\text {it-1 }}$ & & & & & $\begin{array}{c}0.0284 * * \\
(0.006)\end{array}$ \\
\hline DIV $_{\text {it }}$ & $\begin{array}{l}0.2621 \\
(0.108)\end{array}$ & $\begin{array}{c}0.2030^{*} \\
(0.095)\end{array}$ & $\begin{array}{c}0.2839 * \\
(0.103)\end{array}$ & $\begin{array}{c}0.3145^{*} \\
(0.165)\end{array}$ & $\begin{array}{l}0.2068 \\
(0.802)\end{array}$ \\
\hline $\mathbf{M R}_{\mathrm{it}}$ & $\begin{array}{l}0.0092 \\
(1.004)\end{array}$ & $\begin{array}{c}0.0146^{*} \\
(0.904)\end{array}$ & $\begin{array}{c}0.0104 * * * \\
(0.001)\end{array}$ & $\begin{array}{c}0.0197 * * \\
(0.007)\end{array}$ & $\begin{array}{l}0.0168 \\
(0.908)\end{array}$ \\
\hline BSIZE & $\begin{array}{l}0.0668 \\
(0.389)\end{array}$ & $\begin{array}{l}0.0647 \\
(1.076)\end{array}$ & $\begin{array}{c}0.0742 * * * \\
(0.005)\end{array}$ & $\begin{array}{c}0.0596^{*} \\
(0.014)\end{array}$ & $\begin{array}{c}0.0689^{*} \\
(0.878)\end{array}$ \\
\hline BINDit & $\begin{array}{c}0.0645^{*} \\
(0.031)\end{array}$ & $\begin{array}{c}0.0793^{*} \\
(0.037)\end{array}$ & $\begin{array}{c}0.0581^{*} \\
(0.029)\end{array}$ & $\begin{array}{l}0.0672 \\
(0.915)\end{array}$ & $\begin{array}{l}0.0708 \\
(0.805)\end{array}$ \\
\hline
\end{tabular}
ratio; DIVit = Dividend payout ratio; ISIit= investors' confidence; Xit; a set of control variable firm's size (FSIZEit), Sales (SALEit), market risk (MRit) and firm's age (AGEit)

Table-5 Financial Policies at (50\% cut off point) 


\begin{tabular}{lccccc}
\hline SENTIit & $0.0347^{*}$ & 0.0278 & $0.0446^{* *}$ & $0.0245^{*}$ & $0.0490^{*}$ \\
& $(0.018)$ & $(0.932)$ & $(0.024)$ & $(0.016)$ & $(0.024)$ \\
FSIZEit & 0.0450 & 0.0569 & 0.0608 & 0.0413 & $0.0814^{*}$ \\
& $(1.071)$ & $(0.086)$ & $(0.392)$ & $(2.098)$ & $(0.064)$ \\
SALEit & 0.0124 & 0.0138 & 0.0217 & 0.0185 & 0.0147 \\
& $(1.071)$ & $(2.004)$ & $(0.042)$ & $(0.702)$ & $(0.891)$ \\
ROAit & $-0.0260^{* * *}$ & $-0.0168^{*}$ & $0.0362^{*}$ & 0.0458 & $0.0702^{*}$ \\
& $(0.001)$ & $(0.011)$ & $(0.018)$ & $(0.716)$ & $(0.036)$ \\
AGEit & $0.196^{* *}$ & $0.162^{*}$ & $0.123^{*}$ & $0.138^{*}$ & $0.169^{*}$ \\
& $(0.089)$ & $(0.036)$ & $(0.061)$ & $(0.067)$ & $(0.089)$ \\
Time dummy & Yes & Yes & Yes & Yes & Yes \\
Country dummy & Yes & Yes & Yes & Yes & Yes \\
R2 & 58.60 & 68.91 & 58.35 & 39.81 & 39.81 \\
\hline
\end{tabular}

Note: this table shows the time series cross section results of financial decisions of family and non-family firms at $50 \%$ cut off point. FOF is dummy for family ownership equal 1 , otherwise zero. BH dummy variable equal 1 for presence of block holder's effect and zero otherwise. The INVit and IAIit are the corporate investment and industry adjusted investment. LEVit and DIVit are the debt ratio and dividend payout ratio respectively BSIZEit and BINDit are board independent and board size use as proxy for corporate governance. IFit stands for internal fund; ISIit; investor confidence; Qit denotes Tobin q; and NEit is the net earnings of firms. CFit is cash flow and MRit, market risk, ROAit is return on assets, FSIZEit is firm size, SALEit is firm sales and AGEit is age of firms. *** Significant at $1 \%, * *$ significant at $5 \%$ level $\& *$ significant at $10 \%$ level respectively.

The table-5 provides the results of model (1-5), which indicate the insight regarding financial behavior of FOFs and NFOFs. The financial behavior of the firms can be categorized into two parts. The first part analyses the investment behaviors of the firms. The first two hypotheses are designed to examine investment behavior. The hypothesis-1 deals with internal fund-investment sensitivity in line with Pecking order theory. The findings indicate a positive (significant) impact of cash flow on investment is more for NFOFs than FOFs. On the other hand, investment sensitivity is less in FOFs than NFOFs. Thus, hypothesis-1 is accepted as the results found statistically significant. Our findings support the previous studies, like (Pindado and de la Torre, 2009 and Koo and Maeng, 2006). Similarly, it is found that block holders has insignificant impact on investment sensitivity.

The second part investigates the debt and dividend policies regarding FOFs and NFOFs under shadow of Pecking order theory as well as trade-off theory. These findings indicate the impact of internal fund on LEV for NFOFs is $(\beta=-0.140)$ and for FOFs $(\beta+\gamma=-0.140+$ $0.078=-0.062)$. The coefficients of NFOFs is $(\beta 1=0.004)$ and for FOF is $(\beta 1+\gamma 1)=(0.004$ $+0.015=0.019$ ) which indicate a positive (significant) impact of net earnings on dividend payment. These results are consistent with previous studies (Gugler, K. 2003; Sáez \& Gutiérrez, 2015 and among others) and don't consistent with the arguments of substation effect between ownership structure and dividend policy (Goergen, et al., 2005). The results at $25 \%$ threshold point remain unchanged and robust the previous evidences. There is a significant difference on both threshold points. Empirical results on $25 \%$ threshold point can be seen in table- 7 below. 
Table-6 Financial Policies at (50\% cut off point)

\begin{tabular}{|c|c|c|c|c|c|c|}
\hline Variables & & Model 1 & Model 2 & Model 3 & Model 4 & Model 5 \\
\hline Constant & $\mathrm{C}_{\mathrm{o}}$ & $\begin{array}{c}-0.0264^{*} \\
(0.006)\end{array}$ & $\begin{array}{c}-0.0359^{*} \\
(0.006)\end{array}$ & $\begin{array}{c}0.0248 * * * \\
(0.001)\end{array}$ & $\begin{array}{r}0.0196 \\
(0.571) \\
\end{array}$ & $\begin{array}{c}0.0208 \\
(0.901) \\
\end{array}$ \\
\hline IFit & $\alpha_{0}$ & $\begin{array}{c}0.1638^{* *} \\
(0.065) \\
\end{array}$ & $\begin{array}{c}-0.1382 * \\
(0.098)\end{array}$ & $\begin{array}{c}-0.1446^{*} \\
(0.092)\end{array}$ & $\begin{array}{l}0.1368 \\
(0.695)\end{array}$ & $\begin{array}{c}0.1308 * * \\
(0.043)\end{array}$ \\
\hline FOF*IFit & $\gamma$ & $\begin{array}{c}-0.0994 * * * \\
(0.007)\end{array}$ & $\begin{array}{l}-0.0590 \\
(0.365) \\
\end{array}$ & $\begin{array}{l}0.0796 \\
(0.094) \\
\end{array}$ & & \\
\hline BH*IFit & $\delta$ & & $\begin{array}{c}0.0054 * \\
(0.003)\end{array}$ & & & \\
\hline NEit & $\beta 1$ & & & & & $\begin{array}{c}0.0082 * * * \\
(0.003)\end{array}$ \\
\hline FOF*NEit & $\gamma$ & & & & & $\begin{array}{c}0.0189 * * * \\
(0.002)\end{array}$ \\
\hline IAIit-1 & $\Phi$ & $\begin{array}{c}0.0129 * * * \\
(0.001)\end{array}$ & $\begin{array}{l}0.0126 \\
(0.082) \\
\end{array}$ & & & \\
\hline $\mathrm{LEV}_{\text {it-1 }}$ & $\Phi 1$ & & & $\begin{array}{c}0.2296 * * * \\
(0.041)\end{array}$ & & \\
\hline $\mathrm{DIV}_{\mathrm{it}-1}$ & $\Phi 2$ & & & & $\begin{array}{c}0.2184 * * \\
(0.081)\end{array}$ & \\
\hline$\overline{Q_{i t-1}}$ & $\delta 1$ & $\begin{array}{c}-0.0116^{* * * *} \\
(0.002) \\
\end{array}$ & $\begin{array}{c}-0.0164 * * * \\
(0.001)\end{array}$ & & & \\
\hline $\mathrm{MR}_{\mathrm{it}}$ & $\beta 2$ & $\begin{array}{l}0.031^{*} \\
(0.019) \\
\end{array}$ & & & & \\
\hline BSIZE & $\beta 3$ & $\begin{array}{c}0.1348 * * \\
(0.058)\end{array}$ & $\begin{array}{l}-0.1246^{*} \\
(0.0604)\end{array}$ & $\begin{array}{c}-0.1409^{*} \\
(0.092)\end{array}$ & $\begin{array}{c}0.1608 * \\
(0.108)\end{array}$ & $\begin{array}{c}0.1346^{*} \\
(0.098)\end{array}$ \\
\hline BIND & $\beta 4$ & $\begin{array}{c}0.1638 * * \\
(0.075)\end{array}$ & $\begin{array}{c}-0.1024^{*} \\
(0.059)\end{array}$ & $\begin{array}{l}-0.1436 \\
(0.132)\end{array}$ & $\begin{array}{c}0.1358 * * * \\
(0.005)\end{array}$ & $\begin{array}{c}0.1468 \\
(0.090)\end{array}$ \\
\hline SENTIit & $\beta 5$ & $\begin{array}{c}0.1308^{*} \\
(0.005) \\
\end{array}$ & $\begin{array}{c}0.1219^{* * *} * \\
(0.001)\end{array}$ & $\begin{array}{c}0.1236 * * * \\
(0.002)\end{array}$ & $\begin{array}{c}0.0954 * * * \\
(0.000)\end{array}$ & $\begin{array}{c}0.4790 * * * \\
(2.017)\end{array}$ \\
\hline $\mathrm{CF}$ & $\beta 6$ & $\begin{array}{c}0.0392 * * * \\
(0.005) \\
\end{array}$ & $\begin{array}{c}0.0368^{*} \\
(0.019) \\
\end{array}$ & $\begin{array}{c}0.0306 * * * \\
(0.007)\end{array}$ & $\begin{array}{l}0.0259 \\
(0.094) \\
\end{array}$ & $\begin{array}{l}0.0274 \\
(0.076)\end{array}$ \\
\hline ROAit & $\beta 9$ & $\begin{array}{c}-0.0236 * * * \\
(0.007) \\
\end{array}$ & $\begin{array}{c}-0.0264 \\
(0.058)\end{array}$ & $\begin{array}{c}0.0069^{* *} \\
(0.008)\end{array}$ & $\begin{array}{c}0.0316 * * * \\
(0.000)\end{array}$ & $\begin{array}{l}0.0309 \\
(0.038)\end{array}$ \\
\hline FSIZEit & $\omega 1$ & $\begin{array}{c}0.0289 * * * \\
(0.002)\end{array}$ & $\begin{array}{c}0.0649 * \\
(0.036)\end{array}$ & $\begin{array}{l}0.4139 \\
(0.253)\end{array}$ & $\begin{array}{c}0.362 * * \\
(0.102)\end{array}$ & $\begin{array}{l}0.3490 \\
(0.523)\end{array}$ \\
\hline SALEit & $\omega 2$ & $\begin{array}{l}0.0019 \\
(0.301)\end{array}$ & $\begin{array}{l}0.0038 \\
(0.504)\end{array}$ & $\begin{array}{l}0.0219 \\
(0.832)\end{array}$ & $\begin{array}{c}0.0264 * * * \\
(0.002)\end{array}$ & $\begin{array}{c}0.0236 * * * \\
(0.009)\end{array}$ \\
\hline AGEit & $\omega 3$ & $\begin{array}{c}0.0028 * * * \\
(0.000)\end{array}$ & $\begin{array}{c}0.0130 * * * \\
(0.031)\end{array}$ & $\begin{array}{c}-0.0128 \\
(0.401)\end{array}$ & $\begin{array}{c}-0.0259 \\
(0.073)\end{array}$ & $\begin{array}{c}-0.0236 \\
(0.185)\end{array}$ \\
\hline R2 & $\mathrm{r}$ & $0.426^{*}$ & $0.524 *$ & $0.592^{*}$ & $0.405^{*}$ & $0.525^{*}$ \\
\hline Sargan & & 0.468 & 0.409 & -0.112 & -0.829 & -0.625 \\
\hline
\end{tabular}

Note: This table presents the results of financial decisions of family and non-family own firms at $25 \%$ cut off point. FOF dummy for family own firms and $\mathrm{BH}$ dummy for presence of blockholders effect; while INVit and IAIit are the corporate investment and industry adjusted investment. LEVit and DIVit are the debt ratio and dividend payout ratio respectively BSIZEit and BINDit are board independent and board size use as proxy for corporate governance. IFit stands for internal fund; ISIit; investor confidence; Qit denotes Tobin q; and NEit is the net earnings of firms. CFit is cash flow and MRit, market risk, ROAit is return on assets, FSIZEit is firm size, SALEit is firm sales and AGEit is age of firms. 
Table-7 Financial Policies at (25\% cutoff point)

\begin{tabular}{|c|c|c|c|c|c|}
\hline Variables & OLS & $\mathrm{RE}$ & $2 \mathrm{SL}$ & $2 \mathrm{SL}$ & $2 \mathrm{SL}$ \\
\hline Constant & $\begin{array}{c}0-0.0453^{*} \\
(1.036)\end{array}$ & $\begin{array}{c}-0.0509 * \\
(0.872)\end{array}$ & $\begin{array}{c}0.0429^{*} \\
(0.708)\end{array}$ & $\begin{array}{l}0.0508^{*} \\
(0.703)\end{array}$ & $\begin{array}{l}0.0529^{*} \\
(0.982)\end{array}$ \\
\hline $\mathrm{IF}_{\text {it }}$ & $\begin{array}{c}-0.0629 * \\
(1.642)\end{array}$ & $\begin{array}{l}-0.0694 \\
(1.809)\end{array}$ & $\begin{array}{c}-0.0625 \\
(1.086)\end{array}$ & $\begin{array}{l}-0.0706 \\
(1.078)\end{array}$ & $\begin{array}{c}-0.0895 \\
(0.097)\end{array}$ \\
\hline $\mathrm{FOF}^{*} \mathrm{IF}_{\mathrm{it}}$ & $\begin{array}{c}-0.1396 * \\
(0.907)\end{array}$ & & $\begin{array}{c}-0.1284^{*} \\
(0.934)\end{array}$ & $\begin{array}{c}-0.1269^{*} \\
(1.905)\end{array}$ & \\
\hline$\overline{\mathrm{BH} * \mathrm{IF}_{\mathrm{it}}}$ & $\begin{array}{l}-0.0368 \\
(0.981)\end{array}$ & & & & \\
\hline $\mathrm{NE}_{\text {it }}$ & $\begin{array}{l}0.0345^{*} \\
(1.746) \\
\end{array}$ & & & & \\
\hline $\mathrm{FOF}^{*} \mathrm{NE}_{\mathrm{it}}$ & $\begin{array}{c}0.0149^{*} \\
(0.972)\end{array}$ & & & & \\
\hline$\overline{\mathrm{Q}_{\text {it }}}$ & $\begin{array}{l}-0.0138 \\
(0.976)\end{array}$ & & & & \\
\hline$\overline{\mathrm{Q}_{\mathrm{it}-1}}$ & & & $\begin{array}{c}0.0198 * * \\
(0.008) \\
\end{array}$ & & \\
\hline $\mathrm{IAI}_{\mathrm{it}-1}$ & & & & $\begin{array}{c}0.0196^{*} \\
(0.014)\end{array}$ & \\
\hline $\mathrm{CF}_{\text {it }}$ & $\begin{array}{l}0.0190 \\
(0.062)\end{array}$ & $\begin{array}{r}0.0225 \\
(0.097)\end{array}$ & $\begin{array}{r}0.0316 \\
(0.325)\end{array}$ & $\begin{array}{c}0.0394 * * * \\
(0.001)\end{array}$ & $\begin{array}{l}0.0417 * \\
(0.028) \\
\end{array}$ \\
\hline$\overline{\mathrm{CF}_{\mathrm{it}-1}}$ & & & & & $\begin{array}{l}0.0284^{*} \\
(0.018)\end{array}$ \\
\hline$\overline{\mathrm{DIV}_{\text {it }}}$ & $\begin{array}{c}0.2456^{* * * *} \\
(0.009)\end{array}$ & $\begin{array}{l}0.2122^{*} \\
(0.0814)\end{array}$ & $\begin{array}{c}0.2096^{*} \\
(0.056)\end{array}$ & $\begin{array}{c}0.2706^{* *} \\
(0.092)\end{array}$ & $\begin{array}{l}0.2140^{*} \\
(0.0917)\end{array}$ \\
\hline $\mathrm{MR}_{\mathrm{it}}$ & $\begin{array}{l}0.0987 \\
(0.693) \\
\end{array}$ & $\begin{array}{l}0.1286 \\
(0.950) \\
\end{array}$ & $\begin{array}{l}0.1360^{*} \\
(0.063)\end{array}$ & $\begin{array}{l}0.1689^{*} \\
(0.802) \\
\end{array}$ & $\begin{array}{l}0.0159^{*} \\
(0.005)\end{array}$ \\
\hline$\overline{\text { BSIZE }_{i t}}$ & $\begin{array}{l}0.0609 \\
(0.074) \\
\end{array}$ & $\begin{array}{c}0.0529 * * \\
(0.0194) \\
\end{array}$ & $\begin{array}{l}0.0620 \\
(0.573) \\
\end{array}$ & $\begin{array}{c}0.0574 * * \\
(0.029) \\
\end{array}$ & $\begin{array}{l}0.0542 * \\
(0.029) \\
\end{array}$ \\
\hline $\mathrm{BIND}_{\mathrm{it}}$ & $\begin{array}{l}0.0601^{*} \\
(0.009)\end{array}$ & $\begin{array}{l}0.0680^{*} \\
(0.032)\end{array}$ & $\begin{array}{c}0.06063^{*} \\
(0.031)\end{array}$ & $\begin{array}{l}0.0598 \\
(0.981)\end{array}$ & $\begin{array}{l}0.0610^{*} \\
(0.049)\end{array}$ \\
\hline$\overline{\text { SENTI }_{i t}}$ & $\begin{array}{l}0.2984 * \\
(0.170)\end{array}$ & $\begin{array}{l}0.3096 \\
(1.001)\end{array}$ & $\begin{array}{c}0.3469 * * \\
(0.192)\end{array}$ & $\begin{array}{l}0.2869^{*} \\
(0.172)\end{array}$ & $\begin{array}{c}0.3196 * * \\
(0.082)\end{array}$ \\
\hline FSIZE $_{\text {it }}$ & $\begin{array}{l}0.0408^{*} \\
(0.029) \\
\end{array}$ & $\begin{array}{l}0.0425 \\
(0.708) \\
\end{array}$ & $\begin{array}{l}0.0480 \\
(0.904) \\
\end{array}$ & $\begin{array}{l}0.0408 \\
(1.004) \\
\end{array}$ & $\begin{array}{c}0.0396 * * \\
(0.018) \\
\end{array}$ \\
\hline SALE $_{\text {it }}$ & $\begin{array}{l}0.1864 \\
(1.009) \\
\end{array}$ & $\begin{array}{c}0.1908 * * \\
(0.039) \\
\end{array}$ & $\begin{array}{c}0.2496 * * \\
(0.009) \\
\end{array}$ & $\begin{array}{l}0.2064 \\
(0.826) \\
\end{array}$ & $\begin{array}{c}0.2018^{* * *} \\
(0.091) \\
\end{array}$ \\
\hline $\mathrm{ROA}_{\mathrm{it}}$ & $\begin{array}{c}-0.0260^{*} \\
(0.017)\end{array}$ & $\begin{array}{c}-0.0209 * * * \\
(0.003)\end{array}$ & $\begin{array}{l}0.0264^{*} \\
(0.019)\end{array}$ & $\begin{array}{c}0.0386 * * * \\
(0.008)\end{array}$ & $\begin{array}{c}0.0402 * * \\
(0.018)\end{array}$ \\
\hline $\mathrm{AGE}_{\text {it }}$ & $\begin{array}{l}0.1486^{*} \\
(0.081) \\
\end{array}$ & $\begin{array}{l}0.1394 \\
(0.695) \\
\end{array}$ & $\begin{array}{l}0.1264 * \\
(0.051)\end{array}$ & $\begin{array}{c}0.1358 * * * \\
(0.008)\end{array}$ & $\begin{array}{l}0.1486^{*} \\
(0.094)\end{array}$ \\
\hline Time dummy & Yes & Yes & Yes & Yes & Yes \\
\hline Country dummy & Yes & Yes & Yes & Yes & Yes \\
\hline R2 & 56.30 & 60.70 & 54.50 & 46.31 & 49.30 \\
\hline
\end{tabular}

Note: This table presents the regression results of financial decisions of family and nonfamily companies' at $25 \%$ cut off point. FOF dummy for family own firms and BH dummy for presence of blockholders effect. INVit and IAIit are the corporate investment and industry adjusted investment. LEVit is debt ratio and DIVit is dividend payout ratio. BSIZEit and BINDit are board independent and board size use as proxy for corporate governance. IFit stands for internal fund; ISIit; investor confidence; Qit denotes Tobin q; and NEit is the net earnings of firms. CFit is cash flow and MRit, market risk, ***at $1 \%, * *$ at $5 \%$ \&* significant at $10 \%$ level respectively. 


\section{CONCLUSIONS AND RECOMMENDATIONS}

The finding of this paper overall indicates that FOFs exhibit lower sensitivities between investment and cash flow. In view of such sensitivities, asymmetric information is explained as a supportive aspect of FOFs. Moreover, findings show that FOFs are willing to condense overinvestment and underinvestment difficulties, which permit FOFs to achieve the best possible level of corporate investment. Such type of understanding supports the arguments that FOFs craft their value efficiently through best investment decisions. Furthermore, it is important to emphasize that there is a positive and statically frail relationship between investment and cash inflow that describe the important attribute of FOFs. One more attribute of FOFs is ownership structures that is accounted for when probing how family control influences the sensitivity of investment, whether the presence block holders in the management. Our finding suggests presence of block holders in decisionmaking process is meaningless as the result is statistically insignificant.

Regarding financing decisions, the main judgments of this study are; firstly, the cash flow has a significant impact on leverage ratio which indicates a weak application of pecking order theory in family owned business. Moreover, the findings provide the explanation about asymmetric information problems that are less severs in FOFs, which permit firms to get access to external funds easily as compare to non-family own firms. Moreover, this result indicates the lower agency problem between owners and creditors, as results, a lower cost of financing (Anderson \& Reeb, 2003). Secondly, dividend payout ratios are higher in family firms that provide interpretations to outcome model of dividend (Chae et al., 2009). It indicated that owners have a large stake in FOFs that forced managers to allocate higher amount of net earnings as dividend among shareholders (Sáez \& Gutiérrez, 2015). This study evidenced that there are efficient dividend policies in family own business as they face a severe cash-flow problems. Thus, the dividend policies of FOFs are according to the free cash flow understanding of dividend models (Jensen, 1986). The following recommendations are for policy maker and other beneficiaries; as FOFs reveal lowers investment-cash flow sensitivities asymmetric information and agency problems. These findings suggest to the regulatory authority to take some actions that can improve the family firms business in the GCC markets. This study suggested to the investors to prioritize their investments comparatively in family business. The regularity authority is advised to enforce the firm to execute their dividend policy, particularly for non-family own firm.

\section{REFERENCES}

Al-Ghamdi, M., \& Rhodes, M. (2015). Family Ownership, Corporate Governance and Performance: Evidence from Saudi Arabia. International Journal of Economics and Finance, 7(2), 78-86.

Almeida, H., \& Campello, M. (2010). Financing Frictions and the Substitution betweenInternal and External Funds. Journal of Financial and Quantitative Analysis, 45(03), 589-622.

Allegretto, S.A., Dube, A. \& Reich, M. (2011). Do minimum wages really reduce teen employment? Accounting for heterogeneity and selectivity in state panel data. Industrial Relations, 50(2), 205-240.

Anderson, R. C., \& Reeb, D. M. (2003). Founding Family Ownership, Corporate Diversification, and Firm Leverage. Journal of Law and Economics, 46(2), 653-684. 
Chae, J., Kim, S., \& Lee, E. J. (2009). How corporate governance affects payout policy under agency problems and external financing constraints. Journal of Banking \& Finance, 33(11), 2093-2101.

Chase Peterson-Withorn (2015). New Report Reveals The 500 Largest Family-Owned Companies in the World. Forbes [online] available at http://www.forbes.com/chasewithorn/new-report-reveals-the-500-largest-familyowned-companies-in-the-world/

Chaussé, P. (2010). Computing generalized method of moments and generalized empirical likelihood with R. Journal of Statistical Software, 34(11), 1-35.

Demsetz, H., \& Villalonga, B. (2001). Ownership structure and corporate performance.Journal of Corporate Finance, 7, 209-233.

Denis, D.J., \& Osobov, I. (2008). Why do firms pay dividends? International evidenceonthe determinants of dividend policy. Journal of Financial Economics, 89, 62-82.

De Miguel, A., Pindado, J., \& De la Torre, C. (2004). Ownership structure and firm value: New evidence from Spain. Strategic Management Journal, 25(12), 1199-1207.

De Cesari, A., \& Ozkan, N. (2015). Executive incentives and payout policy: Empirical evidence from Europe. Journal of Banking \& Finance, 55, 70-91.

Doidge, C., Karolyi, G. A., Lins, K. V., Miller, D. P., \& Stulz, R. M. (2009). Private benefits of control, ownership, and the cross-listing decision. The Journal of Finance, 64(1), 425-466.

Frank, M. Z., \& Goyal, V. K. (2009). Capital structure decisions: which factors are reliably important?. Financial management, 38(1), 1-37.

Galeotti, M., Schiantarelli, F., \& Jaramillo, F. (1994). Investment decisions and the role of debt, liquid assets and cash flow: evidence from Italian panel data. Applied Financial Economics, 4(2), 121-132.

Goergen, M., Renneboog, L., \& Da Silva, L. C. (2005). When do German firms change their dividends?. Journal of corporate finance, 11(1), 375-399.

Gómez-Mejía, L. R., Haynes, K. T., Núñez-Nickel, M., Jacobson, K. J., \& Moyano-Fuentes, J. (2007). Socioemotional wealth and business risks in family-controlled firms: Evidence from Spanish olive oil mills. Administrative science quarterly, 52(1), 106137.

Gugler, K. (2003). Corporate governance, dividend payout policy, and the interrelation between dividends, R\&D, and capital investment. Journal of Banking \& Finance, 27(7), 1297-1321.

Hail, L., Tahoun, A., \& Wang, C. (2014). Dividend payouts and information shocks. Journal of Accounting Research, 52(2), 403-456.

Hovakimian, G. (2009). Determinants of investment cash flow sensitivity. FinancialManagement, 38(1), 161-183.

Jensen, M. C. (1986). Agency cost of free cash flow, corporate finance, and takeovers. Corporate Finance and Takeovers. American Economic Review, 76(2), 323-329.

Jensen, M. C., \& Meckling, W. H. (1976). Theory of the firm: Managerial behavior, agency costs and ownership structure. Journal of financial economics, 3(4), 305-360.

Konijn, S. J., Kräussl, R., \& Lucas, A. (2011). Blockholder dispersion and firm value. Journal of Corporate Finance, 17(5), 1330-1339.

McVey, H. \& J. Draho (2005). U.S. Family-Run Companies-They May Be Better thanYou Think. Journal of Applied Corporate Finance 17(4), 134-143.

Meyer, J.R., and Kuh, E. (1957). The investment decision." Harvard University Press,Cambridge, MA, USA 
Miller, D., Le Breton-Miller, I., Lester, R. H., \& Cannella, A. A. (2007). Are family firms really superior performers? Journal of Corporate Finance, 13(5), 829-858.

Modigliani, F., \& Miller, M. H. (1959). The cost of capital, corporation finance, and the theory of investment: Reply. The American Economic Review, 49(4), 655-669.

Morgado, A., \& Pindado, J. (2003). The Underinvestment and Overinvestment Hypotheses: an Analysis Using Panel Data. European Financial Management, 9(2), 163-177.

Myers, S. C., \& Majluf, N. S. (1984). Corporate financing and investment decisions when firms have information that investors do not have. Journal of financial economics, 13(2), 187-221.

Nasrum, M. (2013). The Influence of Ownership Structure, Corporate Governance, Investment Decision, Financial Decision and Dividend Policy on the Value of the Firm Manufacturing Companies Listed on The Indonesian Stock Exchange. Journal Managerial, 1(1).

Porta, R., Lopez-de-Silanes, F., \& Shleifer, A. (1999). Corporate ownership around the world. The journal of finance, 54(2), 471-517.

Sáez, M., \& Gutiérrez, M. (2015). Dividend Policy with Controlling Shareholders. Theoretical Inquiries in Law, 16(1), 107-130.

Sapovadia, V. (2012). Corporate Governance Issues in Indian Family-Based Businesses (No. 55226). University Library of Munich, Germany.

Santos, M. A. (2015). Integrated Ownership and Control in the GCC Corporate Sector (No. 15-184). International Monetary Fund.

Schulze, S., Lubatkin, H., \& Dino, N. (2003). Exploring the agency consequences of ownership dispersion among the directors of private family firms. Academy of Management Journal, 46(2), 179-194.

Sonfield, M. C., Lussier, R. N., \& Fahed-Sreih, J. (2015). Planning for succession in family businesses: a comparison of Arab/Islamic and US practices. International Journal of Business and Globalisation, 15(3), 313-330.

Tahir, S. H., \& Sabir, H. M. (2015). Ownership structures as determinants of financial decisions: evidence from Pakistani family owned listed firms. Zbornik radova Međimurskog veleučilišta u Čakovcu, 6(1), 117-127

Von Eije, H., \& Megginson, W. L. (2008). Dividends and share repurchases in the European Union. Journal of Financial Economics, 89(2), 347-374. 